\title{
REVERSAL CONCEPT OF Truth in Plato
}

\author{
ALEXEI GLOUKHOV \\ National Research University Higher School of Economics \\ agloukhov@hse.ru
}

\begin{abstract}
The paper provides a historical background for the "reversal" concept of truth. In Attic drama, Plato found a way to approach the problem of conflict between the good and justice. By overcoming deficiencies of tragic representations, Plato came to understand human reality as a complex plot, prone to a complete change. His philosophical solution consisted of two steps: the birth of a proper narrative of the good and the verification of this narrative by a corresponding common narrative of justice. This verification is the basis for the reversal concept of truth, traces of which are operative also in Descartes and Heidegger.

KEYWORDS: Plato, tragedy, truth, reversal, the good, justice.

* The article was prepared within the framework of the Academic Fund Program at the National Research University Higher School of Economics (HSE University) in 2018 - 2019 (grant NNo 18-01-0004) and by the Russian Academic Excellence Project «5-100».
\end{abstract}

In this paper, I introduce and explain a concept of truth that may be found in Plato and elsewhere. I have debated between calling it "tragic", "dramatic", or "reversal", bearing in mind the context of ancient Greek tragedy, where "reversal" designates just one of the moments of a complete tragic change. Against this historical backdrop, choosing "reversal" over "tragic" or "dramatic" may be confusing. Ultimately, however, the purpose of my argument is philosophical, not historical. In the context of contemporary debates over truth, calling it "tragic" or "dramatic" is a problematic, whereas "reversal" is both neutral in the contempo- 
rary context and familiar in terms of ancient Greek tragedy. Therefore, I select "reversal" for the title; however, the terms "reversal", "tragic", and "dramatic" are used interchangeably below to refer to the same concept of truth. I prefer calling it "tragic" or "dramatic" in its original historical context and "reversal" in the context of modern and contemporary philosophy.

My reading of Plato is not always conventional, and this paper is hardly a place to defend it. I suggest that the following two assumptions about Plato's political philosophy might be treated at least as a working hypothesis.

First, cognition of "the idea of the good", introduced in book 6 of the Republic, is the ultimate meaning of life for philosophers and, for them, the answer to the question of what is good. ${ }^{1}$ In the same sense, the heroic way of life described in book 5 is the answer to the question of what is the good for guardians. "The good" is unique to a group of "friends" and is what I and my friends mostly or ultimately desire in our life. ${ }^{2}$ Below, I call it "the proper good", as opposed to "common goods", which are not unique and constitute things that everybody usually needs, such as water or money. ${ }^{3}$

\footnotetext{
1 "The good" in the expression "the idea of the good" bears more conceptual weight than the "idea" (therefore, I am reluctant to use the even more technical term "form" instead of "idea"). This expression is similar to the "idea of soul" in Phaedrus, where soul is described as a chariot. In the Republic, the conversation about the "idea of the good" is a pinnacle of the solution to the problem of the conflict between the private pursuit of the good and justice.

${ }^{2}$ In classical terms, "friends" ("philoi") are those who go together in life because they have the same concept of the good, live together ("symbiosis") and, ultimately, go in the same direction in life. See Aristotle. Nicomachean Ethics, books 8-9. In this classical sense, my family and my people are my friends. "Family", in both the literal and metaphorical sense, is a temporal aspect of friendship, where the younger generation of friends follow the lead of the senior generation of friends. The seniors educate the youngsters about the good, and the youngsters follow them voluntarily because they have the same concept of the good, albeit in a nascent state. Since a friend is a second self, I cannot share my concept of the good with my friends because saying so would paradoxically imply that I can give myself something that I am lacking. Only familial education about the good saves us from this paradox. In Plato, the entire warrior class is a group of "friends" or "family". To generalize, we may use the term "my people". In Plato and Aristotle, a group of friends is defined as having the same nature and appropriate nurture.

${ }^{3}$ The wants/needs distinction was employed by John Rawls, who identified the most common needs with "primary goods" and considered wants to be beyond the scope of his theory of justice. He introduced this distinction coming from the side of justice, not from the side of the proper good. Therefore, his distinction suits my interpretation, even if his
} 
Second, we need a specific kind of knowledge, i.e., self-knowledge, to recognize the proper good and a specific kind of speech, which I call "the proper narrative", to express it and to speak of it. Below, I use the term "narrative" very generously as a placeholder for the ancient Greek "logos". ${ }^{4}$ Just as guardians have their own narrative that underpins their entire way of life, so do philosophers have their own narrative, which is what Socrates was struggling to convey to his audience in the central esoteric passages of the Republic.

For the argument in my paper, the point of departure is that ancient Greek tragedy essentially meant two things to Plato (sections 1-2). It was capable of revealing a problem, which was to become the key problem of his philosophy, and it did so by using three artistic devices, which also proved to work for Plato. However, the solution to the problem suggested by the tragedians was politically biased and philosophically inadequate, which had consequences. First, Plato's tackling of this inadequacy led him to a far-reaching conclusion that any given representation of reality is unreliable and prone to a sudden change (section 3). Second, his own philosophical solution involved a specific method of verification (section 4), which served as the basis for the "reversal" concept of truth (section 5). The last section, section 6, invokes some parallels in Descartes and Heidegger that show that the reversal concept of truth is not limited to the ancient Greek context.

\section{Plato's Use of Tragic Art}

Much has been said about Plato's relations with tragedy. I am following just one lead, which explores the possibility that Plato was a competitor, rather than an enemy, of the tragedians. ${ }^{5}$ As a competitor, Plato was an engaged practitioner of the same sport, that is, scripted dramatic performance. Evidence in favor of this interpretation is supplied by his biography and his writings. The same competitive, as opposed to hostile, attitude is presented in numerous sources - ranging from stories about the young Plato nearly embarking on a career as a tragedian, only to turn to philosophy owing to Socrates, to the famous passage in his last

"primary goods" are common goods in my terms and have nothing to do with the proper good.

${ }^{4}$ I do not make any assumptions about the form or content of a narrative, apart from the general characterization of its possible purposes as one of two things: it is either an expression of the proper good (in what I call "proper narratives") or a means of securing the common good (in "common narratives"). Not every speech usage serves these purposes, but the dramatic narratives of tragedians, philosophers, and historians, which are the focus of my paper, mostly do.

${ }^{5}$ See, e.g. Kuhn 1941, 2. 
dialogue, where his mouthpiece, an Athenian elder, calls the conversation an example of "the truest tragedy", openly challenging the tragedians (Laws 817b).

First, I touch upon a few essential features of tragic art where some continuity is discernable on Plato's part. Then, I show how and why Plato developed, even perfected and ultimately overcame the tragic legacy.

The first feature is linguistic. A typical tragedy is an interplay of two kinds of speech. One kind is easily accessible to everyone; it is clear, consecutive, argumentative, suitable to questioning and justifications, and intended to be shared by a speaker with others, whether they are conversational partners or the audience. In tragedies, this kind is mostly found in dialogical "episodes", written in routine, almost prosaic iambic verses of the common Attic dialect. ${ }^{6}$ In Plato, these are the signature sections of his dialogues, where Socrates trades questions and answers with his interlocutors.

However, a different kind of speech is discernable both in tragedies and in Plato, requiring effort on the part of the audience to grasp its meaning. In tragedy, this kind is confined to choral odes, written in various intricate meters in the Doric dialect, accompanied by music and dance. In Plato, the great speeches, such as Callicles' speech in the Gorgias or Socrates' palinode in Phaedrus, ${ }^{7}$ or Socrates' myths and parables in the Republic and elsewhere may be counted as belonging to this kind of speech, requiring the audience to transcend its commonly shared opinions and to rely on its own insights.

The second feature is dramatic. In the Poetics, Aristotle gives an account of "change" (metabasis), which, as a device of tragic art, is essential to Attic drama. ${ }^{8} \mathrm{~A}$ "complex" tragic plot may include up to three different types of change. The first change is a sudden "reversal" (peripety) of the protagonist's fortune. ${ }^{9}$ The second change is the "discovery" or "recognition" (anagnorisis) of a new piece of information that turns the protagonist's knowledge of himself or of his condition upside down. The third change is "suffering" (pathos), i.e., an extreme change in the protagonist's bodily condition. In a perfect tragedy with a "complex" plot, all three changes are engaged and designed to work in harmony, leading to a sudden and

\footnotetext{
${ }^{6}$ Aristotle calls the iambic "the most colloquial" of all poetic meters, in the Poetics, 10-11.

${ }^{7}$ In Plato's Gorgias, Callicles rounds up his exposition of a non-conventional truth with a quote from Pindar. In Plato's Phaedrus, Socrates jokingly complains that his enthusiasm makes him use epic and dithyrambic meters.

${ }^{8}$ Aristotle, Poetics 10-11.

${ }^{9}$ The precise meaning of the "reversal" in Aristotle's Poetics is open to discussion. Since my focus is on Plato, I understand "reversal" as a device of tragic art producing a radical change in the protagonist's social and political positions in the world, e.g., a shepherd becoming a king.
} 
shocking transformation at the climax of the play. Aristotle's favorite drama was Oedipus the King, where the king's discovery of the truth about his origins leads to his political downfall, self-inflicted blindness and the suicide of the queen. ${ }^{10}$

Plato's own extraordinary application of this dramatic device is the Gyges story from the beginning of the 2nd book of the Republic. A similar narrative about Gyges becoming the king of Lydia is recounted by Herodotus at the beginning of his History. Plato might have borrowed a few basic features of the story from the historian; however, the historian's account nearly lacks dramatization. In contrast, Plato's plot involves all three types of tragic change taking place in harmony. First, Gyges realized that he found a ring of invisibility (hence, the "discovery"); then, he approached the king, seduced the king's wife, and killed him (hence, the "suffering"); finally, he took power, transforming from a simple shepherd to the king himself (hence, the "reversal"). Just as the tragedians used to dramatize ancient myths, Plato dramatized a historical account. Judged by Aristotelian standards, he created a perfect drama: the sudden tripartite transformation spreads as though within a moment from the beginning to the end of a single Greek sentence of Plato's prose."

For tragic change to work effectively, another poetic device is necessary, i.e., the device of extreme dramatization. For tragedy, ordinary life is stupid. The tragedian must always choose exceptional cases, only to drive them further to extremes. In this regard, Plato was remarkably diligent. Glaucon, the narrator of the Gyges story in the Republic, insists that only the most radical examples of human justice and injustice are revealing. It is as though some truths shine brighter only when detached from the baseline of the ordinary.

\section{The Key Problem and its Tragic Solution}

Granted that Plato was a competitor of the tragedians who carefully preserved and even perfected a few outstanding features of tragic art, why was this artistic legacy so important for him as a philosopher? My hypothesis is that both linguistic and dramatic features of tragic art allowed him to access and formulate the key problem of his political philosophy. To make it more accessible, it is worth mentioning that the neoclassical literary theories of the early modern period presented it in terms of the typical tragic conflict between passion and duty. A similar philosophical problem is the focus of many of Plato's dialogues. Most memorably, however, Glaucon presents it to Socrates in the and book of the Republic, which marks the true beginning of the main line of argument of the entire work. The key issue at stake is a seeming conflict between private pursuits of the good

\footnotetext{
${ }^{10}$ Aristotle, Poetics 11.

${ }^{11}$ Plato, Republic $360 a$. This nuance is lost in some translations.
} 
and systemic justice. This conflict starts with confusing terminology, which warrants a brief clarification.

In its proper sense, the good is the ultimate meaning of life for an individual or for a group of like-minded individuals, who are, for example, my "friends", my "family", or "my people". The proper good is not common; it is uniquely "my own" or "our own". In formal terms, the proper good is not sharable with others because it is naturally predetermined. I have the same concept of the good with "my people", but I do not share it with them because "my people" are defined by having the same concept of the good to begin with. Discovering and cultivating their nature, i.e., self-knowledge and appropriate education, are the main challenges related to the proper good. In Plato, a philosopher, such as Socrates, may hope to acquire selfknowledge by his own efforts, but guardians acquire self-knowledge from philosophers. In Glaucon's terminology, the proper good is what is "desired for itself”. It is what humans singularly want and not what humans commonly need.

While, for each natural group of "friends", the proper good is unique, the goods of justice are common and plural. In Glaucon's terminology, justice is “desired for its consequences". Necessary instrumental goods such as money or food are sharable, exchangeable, measurable, and distributable. There is not much to learn or to explore with regard to common goods, apart from the exact underlying mechanism of fair exchange or distribution, which is nothing other than the problem of justice in a narrow sense, discussed by Aristotle and John Rawls but almost intentionally avoided by Plato in the Republic. The Greeks aptly call justice "someone else's good" and, by extension, the common good of the entire polis, which always includes not only friends and families but also unfamiliar fellow citizens and strangers. However unfair, the share and input of others are ineliminable from the basic notion of justice.

Glaucon challenged Socrates to prove that the good and justice are compatible; otherwise, justice is pointless. In an unexamined life, ordinary human beliefs about the good and justice are confused and conflicting. Many people compensate for their lack of self-knowledge with a greed for commonly sharable goods, which inevitably leads to fighting over limited resources. Because of this confusion, private concepts of the good come under suspicion and are mistakenly held to be an impediment to justice as the common good. A cynical "real-world" and "down-to-earth" politics exploits this confusion by proclaiming that in this regard, there is nothing to be done; it is just naturally the case that humans are greedy and in a perpetual state of struggle for power. ${ }^{12}$

\footnotetext{
${ }^{12}$ A paradigm example of the real-world political approach is the Melian Dialogue between Athenians and the islanders, as presented by Thucydides in the $5^{\text {th }}$ book of his History.
} 
While "real-world" politics resists even registering a problem, tragic art made significant progress toward both the recognition of the problem and its solution. Owing to the device of extreme dramatization, it achieved analytic clarity by separating the narrative about the good from the narrative about justice. Owing to the device of tragic change, it showed how, despite being perfectly isolated, these two narratives remain two sides of the same human story. Finally, owing to its linguistic feature, it implied that a solution to this problem might have something to do with the language of these two isolated but intertwined narratives.

Consider Sophocles' Antigone. At the beginning, Creon, the new king of Thebes, seems to care about only the common good of his polis. In doing so, he goes to extremes by condemning all who dare to have private motives for actions such as caring for their family members. Before the tragic change, Creon's narrative is purely about justice. However, everything is changed after his decisions lead to the suicides of his son and wife. This tragic change shows that a complete human life involves both caring about justice and caring about one's own good. After the tragic change, Creon's narrative is exclusively about his private life, about his own good or, in this case, about his fatal loss. Despite the clear artistic isolation, the narratives about the common good and the proper good remain closely intertwined in this tragedy. The intrinsic connection between the narratives prepares not only the downfall of the protagonist but also a specific solution to the key problem offered by the tragedians to their audience. The chorus has the final word, basically saying that it is always safer for humans to adhere to some kind of common ground than to risk everything due to their extraordinary actions. This summation is not a return to the ordinary state of confusion about the good and justice. The chorus survives tragic changes not because of its ignorance but because of its ability to see in isolation both sides of the same story at all times. This conceptual ability corresponds to its linguistical mastery of the two separable but intertwined kinds of human speech. The chorus is the only character in drama who, being one and many, navigates between two different artificial languages, where one is common, open, sharable, and suitable for justifications while the other is uncommon, enigmatic, idiosyncratic, and appropriate for intimate insights.

Despite the progress made, the solution offered by the tragedians was inadequate for political and philosophical reasons. The moral lesson to be learned from a typical drama was conditioned by democratic censorship. ${ }^{13}$ The tragic solution was biased against exceptional personalities with their uncommon understanding of their good. This political bias nullified the analytic openings created by

\footnotetext{
${ }^{13}$ In Plato's Gorgias, Socrates claims that tragic poetry is nothing more than flattery.
} 
tragic art and constrained its development in a philosophically fruitful way. Its linguistic feature, the interplay of two kinds of speech, became formal and petrified. Its dramatic feature, the device of tragic change, failed to become a vehicle of research since it kept delivering the same politically palatable outcome.

Consequentially, Plato did not simply preserve a few memorable features of Greek tragedy in his dialogues; he developed and perfected tragic art to reveal its philosophical potential. He liberated his own dramas from the preordained story arc, where strong personalities always fail while conventional values triumph. The moral of the dramatized Gyges story is exactly the opposite: the unjust person becomes unstoppable. However, Plato did not limit his creativity to the mere overturning of standard dramatic patterns. He made his philosophical dramas a genuine vehicle of research into the human condition. He employed a device of parallel story-telling, as in the drama about the most just person and the most unjust person, which immediately follows the Gyges story in the Republic. He abandoned the singular unidirectional changes of a typical tragic performance in favor of open-ended multilayered narratives with a series of successive changes distributed over a lengthy discussion featuring different perspectives leading to different outcomes. Thus, the comparison of the story of the two lives is subsequently reintroduced and relitigated in a context where the audience's concept of the human soul has already been radically altered. Finally, Plato made our selfknowledge the real point of the tragic discovery.

\section{Philosophical Lessons from Tragic Failure}

However, for Plato, the most consequential lesson from the failure of the tragic solution was related to yet another theatrical device, that of the representation of life by tragedy. ${ }^{14}$ Both Plato and Aristotle agreed that drama imitates or represents life on stage. The concept of imitation ("mimesis") must not be oversimplified. Imitation is a bidirectional relation. In section 4 of the Poetics, Aristotle discusses painting before turning to poetry. They are the same two prominent cases discussed and contrasted by Plato in his notorious treatment of the fine arts. ${ }^{15}$ According to both philosophers, painting is a much less powerful form of art than

\footnotetext{
${ }^{14}$ I use the term "representation" in the broad sense of a given common narrative, i.e. a commonly accessible and sharable narrative, which is given or represented by a presenter to its audience, whereby the political dimension of relations between the presenter and its audience cannot be overlooked. In this sense, we can speak about sensual representations of the world, given to our souls by our bodies. I contrast representations as given common narratives with appropriate common narratives. Unlike the former, the latter are not given to the audience but are created by or with a participation of the author of the proper narrative.

${ }^{15}$ Plato, Republic 10.
} 
poetry; nonetheless, it has some power: humans are willing to see a good picture of something that is painful to look upon in real life. Artistic representation is not simply subordinate to real life; it also has the power to interfere in our relations with reality. As Aristotle says, tragedy moves human souls. ${ }^{16}$ The same psychagogic capacity is the center of Plato's treatment of rhetoric in Phaedrus and of poetry in the Republic.

When discussing imitation, both directions of influence must be considered: a work of art is presented for an audience to judge, but it also has the power to move their souls. Bidirectionality means that intrinsic to every artistic representation is a complex bidirectional narrative. One direction of the story concerns what is represented in the picture or on the stage; the other direction concerns how the presenters influence the audience's concept of reality. The allegory of the cave perfectly captures this bidirectionality through the positioning of the audience between the puppet theater and the shadows on the wall.

The actual theatrical representations in ancient Athens featured this complexity. The democratic political regime conditioned the events on stage, and vice versa. On the surface, Greek tragedy taught its audience to appreciate common values and common narratives. The very optics of the audience, representing the Athenian demos, suited this purpose. However, deeply hidden in a tragic performance was the fact that it had powers to corrupt souls and inspire deviants and tyrants. It was only logical for Plato to point out that such an allegedly democratic form of art as tragedy flourishes under tyranny. ${ }^{17}$

This account of representation doubles tragic change. Separable but intertwined narratives must be carefully discerned not only within the tragic plot itself but also in the totality of the theatrical experience, where a staged imitation of human life meets its visual and political representation.

Not by accident, the same nexus is found in Plato's art of writing dialogues, which are thoroughly theatrical to the extent that they are mostly a staged oral performance of presenters before their audience. ${ }^{18}$ Within this logical space, no speech exists by itself without provenance, and every word exchanged is conditioned by the political and ethical relations between speakers and their audience. Plato's philosophic dramas contain implicit or explicit references to the way in which the audience is influenced by representation. The conversational partners suddenly find themselves to be part of a more comprehensive and intimate story

\footnotetext{
${ }^{16}$ Aristotle, Poetics 6.

${ }^{17}$ Plato, Republic 8.

${ }^{18}$ It is so even where only two characters participate, as in Phaedrus. Out in the countryside, Socrates invents a myth about cicadas who are introduced as a partisan and judgmental audience of their conversation.
} 
than they expected. Glaucon is surprised by the seemingly out-of-this-world nature of the allegory of the cave, only to be further surprised by Socrates' invitation to think of the cave prisoners as being "similar to us". The dialectical change that the audience of a dialogue undergoes targets roughly the same three aspects described by Aristotle in relation to tragic change: moral or political progress ("reversal"), epistemic change ("discovery"), and educational change in one's bodily condition ("suffering"). ${ }^{19}$

Considering the device of representation, the general consequence to be drawn is that every theatrical and dialectical performance effectively becomes a "complex" plot. In the Poetics, "complex" plots are mentioned along with "simple" plots, which lack reversals and recognitions. ${ }^{20}$ With the two representational dimensions factored in, even the plainest narratives turn out to be multilayered. Plato's philosophical conclusion was to discard simple plots altogether by considering the entire human reality, including its visual and political dimensions, through the lens of a complex plot, pregnant with sudden change. ${ }^{21}$

The criticism above notwithstanding, for Plato, Attic drama set a helpful example of a meaningful convergence between such topics as politics, language, visuality, and truth. In the Gyges story, justice is identified with a common visual space, whereas the pursuit of a private good is identified with the magic gift of invisibility. This clean optical separation of the two narratives serves the same purpose as the linguistic feature of tragic art. Additionally, the same division of narratives is employed in the central passages of the Republic to isolate two "worlds": the representation of the visual world, related to justice, from the visually inaccessible intelligible world, related to the proper good.

In the Republic, the main line of the investigation into the key problem of political philosophy stretches from one tragic change to another, i.e., from the Gyges story to the allegory of the cave. The investigation begins properly with "Glaucon's challenge" in the 2nd book, including a series of tragic changes in the Gyges story and in the comparison of the story of the two lives, where, along with direct quotes from tragedians, the typical features and devices of tragic art are clearly discernible. This challenge is answered by Socrates in the central passages of the dialogue, with its climax featuring the three allegories of the sun, the divided line, and the cave. In each of these allegories, but most clearly in the allegory of the cave, which is the conclusion and summary of all three, the typical features and devices of tragic art are also discernible.

\footnotetext{
${ }^{19}$ Aristotle, Poetics 11.

${ }^{20}$ Aristotle, Poetics 10.

${ }^{21}$ Among other things, this explains Plato's distrust to written speech. The trouble is that in a written speech the representational dimension is concealed.
} 
Let me summarize my argument thus far. Plato received a kind of twofold help from the tragedians: first, in pinpointing the key problem of compatibility between the proper good and justice; second, in exploring a few artistic devices for presenting this problem to the audience. Plato rejected the solution given in tragedies, which made the chorus and the conventional moral the ultimate basis of all things human. One reason for this rejection was political, i.e., the partisan nature of this solution; the other was philosophical, i.e., its representational character. A narrative of justice was given to the audience. As with any given narrative in a complex plot, it was prone to undergoing a tragic change, leaving those who blindly trusted it empty handed.

This point is brought home by both Glaucon and Adeimantus in the 2nd book of the Republic. Adeimantus denounces the hypocrisy behind the conventional moral by exposing hidden private narratives about the good underlying the generally accepted views about justice. Glaucon proves the same point ex contrario in a more dramatic and personal fashion when he "stages" a tragedy of the most just person. This tragedy warrants particular attention because it contains implicit arguments in favor of the two major theses. The first thesis says that it is unwise to rely on a given common narrative because it literally kills. The second thesis suggests a way out by implying that it is philosophically sound to begin with the creation of a proper narrative.

The most just man is the person who believes that refusing to pursue his own good is the point of justice. In Glaucon's story, the common visual space is a metaphor of the common good, while invisibility is a metaphor of private interests. Using the ring of invisibility is the same as cheating others, which is unjust. Accordingly, the most just man decides that his entire life must be on public display. The tragedy unfolds after he embraces the truth of this tragic solution by going to extremes in following conventional rules. A perfect change comes with his arrest and torture, at which point he finally discovers that he was betrayed by that which he blindly relied upon while neglecting the most important thing in his life, i.e., self-knowledge and the search for the proper good. A specific mechanism of betrayal is also revealed: due to his modesty and unassuming behavior, the most just person is mistaken by his fellow citizens for the most unjust person. This is a tragic mistake; however, in this genre, it is usually the protagonist whose mistake leads to his undoing. A lapse of judgment committed by his fellow citizens would not have been possible if not for a lapse of judgment committed by the most just person himself. Indeed, after having completely renounced his input in defining the rules of the game, it was only a matter of time before the game turned against him. 
A philosophical lesson from this drama is that unless we want to find ourselves in the predicament of the most just person, no given common narrative is reliable. The reason supplied may initially seem extreme: as long as you have no control, nothing prevents the common narrative from justifying your killing at any moment. However, this is exactly what we humans are routinely presented with as part of the legacy narrative about how the world works when we enter life: the common saying that humans are mortal and all are bound to die. It is a matter of human worthiness not to accept any such killer narrative unconditionally.

In Plato, this far-reaching conclusion about the unacceptability of given common narratives affects not only the conventional moral but also all kinds of given representations of the human world. In the Cratylus, conventionalism with regard to language is rejected. In the Phaedrus, Socrates shuns scientific theories because he is still unable to know himself. ${ }^{22}$ In the Republic, the available political regimes and the entire visible world are declared unreliable.

This entails that the first order of business is the creation of a proper narrative about the good, i.e., the pursuit of happiness. Of course, there is always the risk that the private pursuit of the good may conflict with justice. However, it is more philosophically sound to take this risk than not to do so because there remains a chance that the private concept of the good may ultimately turn out to be compatible with what is good for others. Moreover, in Plato, philosophy is defined by its determination to resolve this very conflict.

\section{The Philosophical Solution to the Key Problem}

Plato's philosophical solution gradually transpires. I describe two individual steps toward it that will allow us to draw parallels with Descartes and Heidegger in section 6 below.

The first step is necessitated by the consideration that given common narratives never care about my particular existence. Unhinged, they kill. At the first step, particular survival is the focus. My particular existence is meaningful only for myself; therefore, its story may be rooted only in myself. This step is completed with the birth of a proper author.

The second step goes far beyond that. Its focus is no longer survival but the proper good. To that end, a proper narrative is created by the proper author; it is unique because it is based on self-knowledge and articulates a proper perspective on the meaning of life. The completion of this step is difficult to determine; being the responsibility of the proper author, it seems arbitrary. Nevertheless, at this phase, two interrelated tasks are identifiable, and taken together, they introduce a constraint that allows us to evaluate the completeness of this step meaningfully.

\footnotetext{
${ }^{22}$ Plato, Phaedrus 229e.
} 
The first task is the purification of the proper narrative. All given common narratives must be commonly known and, therefore, countable. Accordingly, the task of purification can be divided into subtasks and proceed methodically. Remnants of given common narratives are to be recognized and eliminated one by one by exposing their dependency on sources alien to the proper author. If the set of representations is hierarchical, then purification becomes recursive. ${ }^{23}$ The inevitable effect of purification is the esoterization of the proper language, which makes the proper narrative ever less accessible to those who do not belong to the group of "friends".

The second task is the verification of the proper narrative through the parallel creation of a new appropriate common narrative. Glaucon's challenge dogmatically assumed that every common narrative collides with private interests. However, this assumption was mistaken. The tragedy of the most just man did not cover common narratives authored by the protagonist. Socrates was able to answer Glaucon's challenge successfully by creating a common narrative of justice that accorded with his own narrative of the good.

In the second step, the two tasks run parallel in opposite directions. The investigation into the good of the philosopher is not complete without a description of a just polis, where appropriate places are provided for philosophers along with those who are different from philosophers, i.e., for warriors, craftsmen, and peasants. This explains why it is meaningful for philosophers to administer justice to others while being absorbed with self-knowledge. A proper narrative is verifiable by justice, if justice is understood in the basic sense of someone else's good. A proper narrative being injustice would mean that someone else was deprived of

\footnotetext{
${ }^{23}$ In a recursive case, it suffices to explain the general principle at one particular level of representation, without explaining the entire path upwards. The recursive feature is crucial for educational communication, which must combine sharable elements with unique ones. Being based on a given structure of representations, the recursive method is sharable with those who can appreciate it. However, the exact direction and the end of this journey is unique and defined solely by the proper author, who is free to pursue her proper good. In the cave allegory, once a prisoner at the bottom of the cave is released and realized what it takes to move upwards to the fire, he can figure out how to proceed even further upwards to the exit, because the upward movement is proper to him and fits his nature. Along these lines, the cave allegory should be read as an invitation to always overcome a given level of representation rather than a simple passage from the phenomenal world to the noumenal world. Indeed, Socrates characterized the idea of good as a limit ("telos") and invites his audience to make a recursive substitution of the sun for the fire and of the idea of good for the sun. This sounds as the invitation to dive into a recursive series of problems, depth of which is measured only by our strife for selfknowledge.
} 
some goods that were theirs. For this deprivation to happen, the goods that changed hands must have been part of a narrative common both to the wrongdoers and to the victims. Money can be such a common good; hence, a craftsman can be deprived of money. On the other hand, a pure proper narrative has no use for common goods such as money; hence, neither warriors nor philosophers would willingly deprive craftsmen of their money. By definition, the proper good has nothing to do with common goods. As Socrates explains, in such a case, less is more. ${ }^{24}$ It follows that a true proper narrative cannot be tyrannical. ${ }^{25}$ Additionally, this explains why no one is willingly unjust. The verification of a proper narrative helps to identify the remnants of given common narratives and, in doing so, to complete the purification of the proper narrative. Philosophers create their own narrative and verify it by creating a new common narrative that is fair to everyone else. ${ }^{26}$

A reversal verification, in which some common narrative is verified by a proper narrative, is also worth noticing. In case such a reversal verification fails, the solution is rolled back to the first step. The alternative case, in which a reversal verification holds, is biconditional: a reversal verification holds if and only if a direct verification holds for the same set of proper and common narratives.

The logic behind this two-way process was sketched in the dialectical section of the Phaedrus, while its practical implementation was discussed at length in the Republic.

\section{The Reversal Truth in Plato}

Both the beginning and the end of the main philosophical argument in the Republic prominently reference truth. Glaucon's challenge is directed against the previous discussion of justice, which, in his opinion, falls short of truth (Rep. II $357 \mathrm{~b}$ ). Socrates' answer, the parables and allegories of the central passages of the Republic, particularly the allegory of the cave, is notorious for its peculiar treatment of truth to the extent that, according to some contemporary philosophers, it determined the fate of the truth concept for centuries thereafter. ${ }^{27}$

Challenging, Glaucon says something to Socrates; answering the challenge, Socrates says something in reply to Glaucon. The conversational partners remain the same; however, their messages are completely different, starting already with their respective kinds of speech. Glaucon gives voice not to his own but to a

${ }^{24}$ Socrates cites Hesiod: "The half is more than the whole" (Plato, Republic 466c).

${ }^{25}$ Tyranny is plagued by impotence of self-knowledge.

${ }^{26}$ The identifiable elements of the appropriate common narrative in the Republic: "the myth of the metals", the definition of justice, the regulations of city space, the food payments in exchange for protection, the religious laws, the basic science.

${ }^{27}$ See "Plato's Doctrine of Truth" in Heidegger 1998b. 
commonly held opinion. In contrast, Socrates owns his speech, which is literally paradoxical, i.e., going against ordinary and commonly held opinions. Glaucon speaks in a commonly comprehensible language that is easily accessible to everyone; his goal is to make his conversational partner justify his position by rejecting or conceding a generally valid argument. Socrates introduces metaphors and parables, which are sometimes so enigmatic that he eventually loses his most loyal audience; his goal is educational.

The main subject of Glaucon's challenge is justice; the main subject of Socrates' answer is the good. Truth is mentioned in both cases but as a secondary subject. In Glaucon's narrative, truth is subordinate to justice; in Socrates' narrative, truth is subordinate to the good. Preliminarily, let us call the first kind of truth the common truth and the second kind of truth the proper truth. Are they the same concept of truth?

Prima facie, the answer is negative. They are two different kinds of truths since they are related to different kinds of speech. A few speech-related differences between the common truth and the proper truth can easily be contrasted, such as the differences in access to, the property rights of, the value of, and the conception of knowledge related to either kind of truth.

The common truth is commonly accessible. Common access is provided within some representation of reality, in the context of which and for which a particular claim can be true or false. There must be commonly accessible methods in place to validate the truth of such claims. The specific field-related methods may vary, as in geometry and law; however, the general principle holds that a true claim must be consistent with a set of axioms or previously verified claims. In this sense, truth is a common achievement; no one has priority in determining it. Everyone is equally positioned in regard to truth because everyone is held to be fallible; everyone's belief may turn out to be true or false. A convenient formula for a common concept of knowledge related to the common truth can be devised, such as "justified true belief". ${ }^{28}$ It is meaningful to wish that everyone has a common short-cut to the conception and content of knowledge that is in the public domain. Finally, inasmuch as common truths are useful, they can hardly be the most precious things in someone's private life.

In contrast, the proper truth is the truth of self-knowledge; it is inaccessible to those who are not "friends", and it is grasped through recollection, through an individual journey, as in the metaphor from the allegory of the cave, from darkness to sunlight, or through appropriate education in a friendly environment. The opinion of outsiders has no influence on the proper truth. For a person who

\footnotetext{
${ }^{28}$ The concept is discussed in Theaetetus 201c-d.
} 
knows himself well, alien judgment means nothing. The proper good is the most important thing in human life; it is humans' perfection and happiness. Only with respect to their own good are people unwilling to tolerate a mistake or rely on a given common opinion. ${ }^{29}$

The aspects listed above are derivable consequences of the primary features of these truths, which are their meanings. Indeed, when we discuss the common truth and the proper truth, a discussion of their meaning must always come first.

The meaning of the common truth is that it secures the success of justice. In this sense, something is true if and only if justice is served, as defined in privileged representation. Not only is the context of Glaucon's challenge a discussion of justice, but he also wants to come to terms with Socrates on this subject by means of justification. On the other hand, the thing that undermines justice more than anything else and that creates the most intricate problems, both in political reality and in his argument, is some private understanding of the good. Most clearly, the relation of the common truth with both justice and the good is described in Plato's Laws. ${ }^{30}$ Truth of this kind is nourished by devotion to justice and is endangered by excessive self-love because a self-loving person values that which is his own more than that which is true. For gods and men, this kind of truth stands above all goods. Three key features of the common truth are evoked: subordination to justice, danger from private interests, and the commanding advantage of truth over everything else except justice.

The meaning of the proper truth is the success of speech about the proper good. In the central passages of the Republic, a similar but inverted set of key features of the proper truth is presented: subordination to the good, danger from given common narratives, and the commanding function of truth. This kind of truth and the respective kind of knowledge are "like the good" ( $\left.\alpha \gamma \alpha \theta_{\circ \varepsilon ı} \delta \hat{\eta}\right)$. The good has clear priority over truth since it is called the source of truth. ${ }^{31}$ Different sorts of given representations of reality and of common narratives - visual, conventional, scientific, political, theatrical - are mentioned in the allegories of the sun, the divided line, and the cave. Without exception, all of them are described as hurdles to be overcome by someone on his educational path to the good. Different levels of reality and common narratives are arranged and evaluated by measuring their participation in this kind of truth. The narrative of the idea of the good in the Republic has a private source, its author and owner. As much as Soc-

\footnotetext{
${ }^{29}$ As Socrates argues in the Republic 505-506.

${ }^{\circ}$ Plato, Laws 73oc-731e.

${ }^{31}$ Plato, Republic 509.
} 
rates tried to make it more accessible, none of his interlocutors was ultimately capable of following him. ${ }^{32}$

This comparison of the two kinds of truth can be reduced to a seeming contradiction in Plato. On the one hand, especially in the central part of the Republic, truth is subordinate to the good and controls everything else. On the other hand, at the beginning of the 2nd book of the Republic but most prominently in the Laws, truth is subordinate to justice and controls everything else. Even if my reading of Plato is unconventional, the burden of explanation for this seeming contradiction regarding truth in Plato remains.

My solution begins by acknowledging that, in fact, two different treatments of truth are found in Plato. However, this is not a mistake or negligence on Plato's part. It is an essential feature of the main philosophical argument in the Republic that it begins with truth in terms of justice and ends with truth in terms of the good. From the beginning to the end of this argument, the concept of truth itself undergoes a complete change, almost like the protagonist in a tragic play.

Can these two understandings of truth be reconciled? On the surface, there may be no logical bridge between them. Both kinds of truth seem to force out their competitor from the corresponding kind of speech. From the perspective of the good, the conventional views of justice held as true by common people are hypocrisy; the commonly accessible knowledge of the visual world is an illusion, just like shadows cast on the wall of a cave. From the perspective of justice, any private truth in relation to other people is injustice or, at best, a "noble lie"33. Like narratives of the good and justice in a tragedy, the two understandings of truth seemingly tolerate each other only in a state of perfect isolation.

However, recall the general context. Philosophy stands out due to its pursuit of a solution to the same kind of hopeless problem, i.e., the problem of compatibility of the good and justice, which are exactly the concepts that lend their meanings to these two understandings of truth. The secondary problem of compatibility of these truths must be no more difficult to resolve than the primary problem of compatibility of the good and justice, which is exactly what Plato undertakes to resolve in the Republic.

Now, suppose that he has succeeded in doing just that. Alternatively, it may be someone else who succeeds in determining how to combine his proper understanding of what is the good for him with the creation of a common narrative about justice. Then, one must acknowledge that these two utterly different understandings of truth are two sides of the same nontrivial concept of truth, which

\footnotetext{
$3^{22}$ See especially Glaucon's complain and exasperation in the Republic 5ogc.

${ }^{33}$ Plato, Republic 414c.
} 
can be called "tragic", "dramatic", or "reversal". Unlike tragic protagonists, the reversal truth is meant to survive a complete change of reality as we know it.

In this way, it becomes clear why, in the Laws, the Athenian elder calls the dialogue an example of "the truest tragedy". The term "tragedy" must recall the key problem of the conflict between the good and justice pinpointed by Attic drama and taken up by Plato. Here, the term "true" designates a successful solution to this problem, which goes well beyond the capabilities of ancient Greek tragedy, despite its artistic power to present on stage both proper and common truths. The philosophical solution is the "truest" of all tragic truths because it finally makes proper truths and common truths compatible.

The proviso that the key problem is resolved serves as a fundamental truth condition. If met, then the proper narratives of the good have been verified by and are compatible with a common narrative of justice. ${ }^{34}$

Truths that are subordinate to the two kinds noted above can be and routinely are defined as though this fundamental truth condition were nonexistent. To give a non-Platonic example, in correspondence theory, which is a standard for contemporary philosophy of science, truth is definable within and for commonly accessible representations of reality. It is defined as an accord between a set of theoretical statements and a set of scientific facts and must account for the revisions necessitated by new discoveries. From the perspective of these cumulative changes, the search for scientific truth functions as the ultimate reason for unstoppable scientific activity. Why do scientists update their theories after new discoveries? They do so in the name of truth. Why do scientists construct new experiments that may potentially bring new discoveries and, therefore, change already updated theories? Again, they do so in the name of truth. However, a different perspective emerges when the entire historical path of science, from its birth to the present, is considered. This path is unmistakably human-bound. It is a perpetual renegotiation of the human place in the universe, a kind of everchanging "contract" or delimitation of the borders between humanity and nature. Not only do humans become aware of ever more scientific facts and laws of nature, but humanity also becomes ever more empowered by this knowledge. We

${ }^{34}$ If the condition is met, justice is compatible with every single proper narrative. In the Republic, there are only two private narratives of the good: one of warriors and one of philosophers. Craftsmen and peasants do not have a proper narrative, since they are defined as those who are satisfied with common goods. The warriors' narrative is crafted by philosophers, who by being first born as warriors themselves know their nature and educate them accordingly. The two proper narratives plus some reasonably fair distribution of money within the economic class fit well into the common narrative, summarized by the formula "each minds their own business". 
abide by the laws of nature as humans, but being scientists, we can also benefit from them. Humans gradually change the power relations with nature and become self-confident, speaking freely for themselves and setting their proper goals in an ever more daring manner. From this perspective, the genuine meaning of scientific activity is much more than the modest search for scientific truth. The familiar key problem resurfaces here as follows: is humans' pursuit of their own good compatible with the natural sciences, understood as a constant renegotiation of the contract between humanity and nature? A positive answer to this question conditions truth as being of a higher order than the scientific order, the reversal truth.

The fundamental truth condition is both philosophical and political (in a general sense that relates to power beyond the polis). It is political because at its core, the problem is political and its solution has political consequences. It is philosophical because despite being political, it is a problem that only philosophy is capable of formulating and always tries to resolve, even if implicitly. Indeed, it may be the problem that defines philosophy.

\section{The Reversal Truth in Descartes and Heidegger}

The reversal concept of truth must not come as a total surprise for students of philosophy. In this section, I discuss two paradigmatic historical cases where a similar concept of truth was implicitly operational. Rene Descartes and Martin Heidegger, who are recognized as the founding fathers of major schools of contemporary philosophy, are selected with the intent to show that the reversal concept of truth has a good chance of bridging some current academic divides.

In his Meditations, Descartes provides a remarkable example of the deployment of devices of tragic art for the sake of philosophy. ${ }^{35}$ Distrusting any given common narratives of reality, including conventional, sensual, religious, and even scientific accounts, he acknowledges that having both true and false beliefs poses no major problem for everyday life. This amounts to a philosophical challenge only after an extreme dramatization of this ordinary predicament. It is at this point that the evil demon ascends the stage. The famous turning point in Descartes's drama accumulates all three features of a complete tragic change. Regarding the "reversal" of power relations, "the malicious demon of the utmost power and cunning" replaces the benevolent God. Regarding the "recognition" of epistemic change, everything the protagonist knew turns out to be a lie. Even regarding "suffering", the protagonist no longer has "hands or eyes, or flesh, or blood or senses". Having earlier described himself as "comfortably sitting by the

\footnotetext{
${ }^{35}$ Cottingham et al. 1984, 12-23.
} 
fire, wearing a winter dressing-gown", Descartes now calls himself a prisoner who has fallen "into a deep whirlpool".

The truth concept undergoes a similar reversal. Descartes rejects representational truths in favor of his proper truth; however, almost immediately and without verification, he transforms his proper truth into a different type of common truth, the innate ideas.

In the first Meditation, Descartes discusses "accepted" truths, which he learned in childhood or acquired via sensual experience. These truths were accepted because they were believed to come from the most secure source, from God, who is "supremely good", meaning that it is beneficial for human beings to accept them. The accepted truths were the bonds of given common narratives. They were sharable goods with common access rights bound to specific representations, which Descartes himself showed step by step while he was falling deeper though the levels of reality following his methodic doubt. In the conclusion of the first Meditation, the tragic change voids all accepted truths and common narratives because of their source in something alien to the protagonist. With the tragic change, a proper author is born, Descartes himself, and according to the logic of his argument, this proper author could not possibly be anyone else.

At birth, his proper narrative consists of only one statement: "I am, I exist", which, according to Descartes, is "necessarily true". The concept of truth that he employs to characterize this statement could not possibly be on par with the accepted common truths mentioned above. The point of his argument is to secure the exact opposite, i.e., that this statement is not represented to him and does not come from anywhere else. Since truth of this kind is related to self-knowledge, it is a proper truth. However, his definition of this truth is ambiguous: "whatever I perceive very clearly and distinctly is true" ${ }^{\prime 36}$. Ever since, scholars have been debating whether "clearly and distinctly" can be defined formally and for everyone, as though it were a common truth. However, eliminating the first-person language from this definition would undermine the crucial "cogito" argument. Speaking for himself but as though in a commonly accessible fashion, Descartes is responsible for this confusion, which he further exacerbates by his "trademark" argument: God exists because I have innate ideas including the idea of God; I have the innate idea of God because in creating me, God placed this idea in me as the mark of His craftsmanship. In the scholarly literature, Descartes is routinely reproached for committing a logical error. Our perspective yields a different and more meaningful explanation. The proper author, to whom Descartes gives birth, never bothers to create a proper narrative or a proper language. He completes his

\footnotetext{
${ }^{36}$ Cottingham et al. 1984, 24.
} 
quest for self-knowledge by resolving the problem of self-existence, never venturing into the problem of the proper good. This is the political meaning of his logical mistake.

One may doubt whether it is fair to align Descartes' argument with a specific argument in Plato. Certainly, if the arguments were unrelated, it would not. However, for these thinkers, these arguments were not random but the most consequential for their definitions of philosophy. More importantly, it is possible to read Descartes's Meditations as though he were following a blueprint of Plato's philosophical solution to the key problem of philosophy, as described above. If this reading works, then why would Descartes ever follow Plato's program?

Descartes completes the first step in an exemplary manner. It is doubtful that he was going to move beyond that. He acknowledges that he thinks differently from others. However, he explains others' inability to understand his thoughts through their unwillingness to detach themselves from their preconceived opinions and from their involvement with the senses. ${ }^{37}$ Other people are happy to rely on given common narratives and "accepted" truths. Instead of thinking about the matter in terms of different concepts of the good, Descartes sees his own genius as a guide for everyone else to follow. From this perspective, others are not moving elsewhere but are lagging; the question is not one of human plurality but of the linear progress of humanity. Since everyone is supposed to eventually archive the same destination, albeit at different speeds, the problem of compatibility between the proper narrative and common narratives disappears. Nevertheless, a comparison with Plato shows striking parallels. As though in harmony with the two-step plan of the philosophical solution, Descartes first creates a proper narrative about the thinking substance and then suggests a new appropriate common narrative about the material substance. On the ontological level, there is a clearcut separation between the two narratives; however, the problem of compatibility is not easily resolved. Descartes resolves it through a double usage of the deus ex machina device. He makes God the primary substance, bridging the material and the immaterial; he also makes God responsible for endowing every human being with the same innate ideas, bridging the differences in human minds.

Although he almost misses the problem itself, Descartes preserves a few phases of Plato's solution. It is against this backdrop that the deficiencies of Descartes's theory stand out. Despite giving birth to the proper author, he never seriously develops a proper narrative about what is the good for him, while his "armchair" common narrative suffers from the absence of real "others", whether they are other human minds or nature as the "other", as in scientific experiments.

\footnotetext{
${ }^{37}$ See the dedicatory letter to the Sorbonne in Cottingham et al. 1984, 5 .
} 
Descartes "succeeds" in resolving Plato's problem only by committing two mistakes: he substitutes the universal language of rationality for proper language, and he substitutes other parties with his own mind while determining the common good. Descartes has been reproached by some philosophers such as Francis Bacon or Michel Foucault for not giving enough credit to otherness in nature or in humans. Our reading shows that Descartes is no more culpable for being unfair to others than for lacking self-interest. In the absence of a full-fledged proper narrative, his common narrative cannot be verified. He is unable to progress without a reversal truth; however, it remains almost an atavism in his philosophy.

Another parallel is from Heidegger, and it develops on two levels. On the surface, Heidegger interprets the fate of the truth concept in the history of philosophy. In Plato's doctrine of truth, he analyzes the allegory of the cave with the intent to demonstrate that Plato substituted the early Greek poetic concept of truth as "unhiddenness" with a metaphysical concept of truth as "correctness" ${ }^{8}$. Elsewhere, Heidegger partly relieves Plato of the responsibility for this event of historical magnitude for all of Western civilization. In the lecture course on Parmenides, Heidegger says that understanding truth as "unconcealedness" was natural for the ancient Greeks, including Plato and Aristotle, while the transformation of the essence of truth into "correctness" was accomplished only later by the ancient Romans. Unlike the Greek concept, the Roman concept of truth as veritas is related to rectitudo and iustitia, correctness and justice. ${ }^{39}$ Heidegger presents his audience with a tragic story of how truth as "unconcealedness" had "withdrawn itself from history" by becoming truth in different sense, defined in terms of justice. A tragic change occurred in the complex plot of the story of Occidental humanity, as a proper narrative of truth was improperly transformed into a common narrative of truth.

Heidegger's story also develops on a more intimate level. As a philosopher, he finds himself in the context of the modern age, understood by him as "the Age of the World-picture", which supplies us with powerful given common narratives and representations. ${ }^{40}$ In Being and Time, he reinvents the lesson of the tragedy of the most just man by arguing that it is the realization of one's own inevitable finitude, "being-toward-death", that leads us to the awakening of our authentic being.

Another possible equivalent to the tragedy of the most just man is found in his lecture "What is metaphysics?"1 "Nothing" is that which the dominant common

\footnotetext{
${ }^{38}$ Heidegger 1998b, $155^{-82 .}$

${ }^{39}$ Heidegger 2005, 6: 49-54.

${ }^{40}$ Heidegger 1977, 115-54.

${ }^{41}$ Heidegger and Carossa 1949.
} 
narrative of metaphysics, which includes science, is able to offer to those seeking the meaning of "being", which was Heidegger's title for the meaning of human existence and his substitute for the concept of the proper good of classical philosophy. Just as, in Glaucon, the moment of total undoing opens the eyes of the most just man to his own good, in Heidegger, the showdown with "nothing" or "being-toward-death" gives birth to an authentic narrative.

On an intimate level, the concept of truth undergoes a dramatic change but in the opposite direction to that in the history of the West. Metaphysical truths of every kind - scientific, philosophic, moral and political, all defined in terms of correctness and justice - turn out to be meaningless, void, repressive, and alien. Instead, a new concept of truth is born, the proper truth as "unhiddenness" or "unconcealedness". Certainly, Heidegger presents this concept of truth as having an unimpeachable pedigree that is deeply rooted in history. However, this is his own concept of truth and his private narrative about truth, if only because he has and preserves an unquestionable priority over anyone else in access to this truth. He never allows this truth to become common property. By insisting that philosophy speaks only German or ancient Greek, he means quite the opposite. In his lecture course on logic, he develops a concept of proper language ("eigentliche Sprache" $)^{42}$; he identifies it with poetry and describes it as the original speech with limited access that has priority over the common logic of rationality that underpins metaphysical narratives.

While Descartes discards differences between human minds, Heidegger exaggerates them to extremes, where it becomes pointless to even ask for common narratives. He is absorbed by creating his proper narrative, but he never intends to complete the second step of Plato's program. Heidegger purifies his proper narrative, making it ever more poetic and esoteric. However, he never verifies it by suggesting a new appropriate narrative of justice. Unsurprisingly, his ended up being tyrannical.

The stark differences between Plato, Descartes, and Heidegger only emphasize the remarkable similarities in how these three philosophers staged their truth dramas, which were meant to define their concepts of philosophy. For these philosophical dramas, it is essential that truth has a doppelganger of a different logical nature and that a concept of truth undergoes a complete change. These foundational stories of Western philosophy would never have been told without the reversal concept of truth operating, even if under the surface, and they never would have received such vivid response from their audiences if not for the devices of tragic art.

\footnotetext{
${ }^{42}$ Heidegger 1998a, 38: 170.
} 


\section{Conclusion}

Above, I present a reversal concept of truth that is different from mainstream contemporary philosophical approaches. The reversal concept of truth has a renowned historical background that dates back to the ancient Greeks. Plato, who borrowed it from the tragedians and perfected it, represents a paradigmatic example of how it can be employed to pinpoint and solve problems in philosophy. In Descartes and Heidegger, the reversal concept of truth also works for their arguments, even if implicitly. A two-step schema of a philosophical solution to the key problem of political philosophy, first identified in Plato and then applied to Descartes and Heidegger, allows a comparison of their strategies. The classical philosophy of Plato (and of Aristotle) is defined by its commitment to resolving the seeming conflict between the good and justice. The two major figures of modern and contemporary philosophy, each in their fashion, avoid this commitment while simultaneously completing parts of Plato's program.

Plato's solution amounts to a verification of a proper narrative of the good by a corresponding common narrative of justice. This verification is the basis of the reversal concept of truth, of which two features are particularly remarkable. The first is a truth condition that is of a higher order than those discussed in contemporary debates about scientific, pragmatic, or poetic truths. The other is the idea that certain kinds of truth may have a generic meaning that precedes internal discussions of truth-meaning relations. For example, representational concepts of truth such as correspondence have a generic meaning of justice, whereas antirepresentational concepts of truth such as poetic or pragmatic concepts have a generic meaning of the good. A more elaborate discussion of the reversal concept of truth itself that goes beyond its historical background in the context of contemporary philosophy, where, as I believe, it may prove to be highly competitive, must be saved for a different paper.

\section{REFERENCES}

Cottingham, John, Dugald Murdoch, Robert Stoothoff, and Anthony Kenny (1984) The Philosophical Writings of Descartes 2. Cambridge University Press.

Heidegger, Martin (1977) The Question Concerning Technology, and Other Essays. Harper \& Row.

Heidegger, Martin (1998a) Gesamtausgabe: Logik als die Frage nach dem Wesen der Sprache. Vol. 38. Vittorio Klostermann.

Heidegger, Martin (1998b) Pathmarks. Cambridge University Press.

Heidegger, Martin (2005) Parmenides. Vol. 6. Ediciones AKAL.

Heidegger, Martin; Hans Carossa (1949) Was ist Metaphysik? Vittorio Klostermann.

Kuhn, Helmut (1941) "The True Tragedy: On the Relationship between Greek Tragedy and Plato, I," Harvard Studies in Classical Philology 52, 1-40.

Rawls, John (2005) Political Liberalism. Columbia University Press. 